Covered in: Erih Plus; HeinOnline; CEEOL; RePEC; CrossRef; Google Scholar; KVK; WorldCat; ICI Journals Master List - Index Copernicus; EBSCO

2021, Volume 8, Issue 2, pages: 35-42 I https://doi.org/10.18662/eljpa/8.2/158

\section{The Natural}

Movement of The

Population in The

Context of the

Pandemic. Statistics

at National Level

Regarding Births,

Deaths, Marriages and Divorces

Irina BILOUSEAC ${ }^{1}$, Andra Ioana DURLEŞTEANU (MECHIŞ) ${ }^{2}$

${ }^{1}$ Associate Professor PhD, "Ştefan cel Mare" University of Suceava, Faculty of Law and Administrative Sciences, Suceava, Romania. irina.bilouseac@,fdsa.usv.ro

2 Bachelor's Graduate, "Ştefan cel Mare" University of Suceava, Faculty of Law and Administrative Sciences, Suceava, Romania.

andra.durlesteanu2@student.usv.ro

\begin{abstract}
The research in this article sheds light on issues related to the evolution of the national situation of the natural movement of the population from January 2019 to May 2021, given the registrations made at the civil registry services in Romania on births, deaths, marriages and divorces, aiming to make a comparison between the period before the pandemic and the period after its onset in our country, in March 2020. We want to see if the number of the four life events mentioned above was really influenced by the pandemic and thus increased or decreased significantly. Also, the study of the natural movement of the population in Romania, under the spectrum of the current health crisis is of major importance, given that the pandemic has visible effects on the acceleration of deaths in people with various comorbidities.
\end{abstract}

Keywords: Births, deaths, marriages, divorces, health crisis, decentralization in public services, statistics from civil registration systems

How to cite: Bilouseac, I., \& Durleşteanu (Mechiş), A. I. (2021). The Natural Movement of The Population in The Context of the Pandemic. Statistics at National Level Regarding Births, Deaths, Marriages and Divorces. European Journal of Law and Public Administration, 8(2), 35-42. https://doi.org/10.18662/elipa/8.2/158 


\section{Introduction}

Since the onset of the pandemic in Romania, in March 2020 and until now, studies have addressed various issues related to COVID-19, but there has been limited activity in terms of the evolution of natural population movement in the context of the health crisis, implicitly four main indicators: births, deaths, marriages and divorces. So this study presents a comparative approach to the natural movement of the population at the national level, using data provided by the National Institute of Statistics, which supply consolidated information that has been obtained from each responsible unit in the country. These statistics from civil registration systems are important to monitor the natural movement of the population, to obtain information on indicators such as births, deaths, marriages and divorces, and to protect the health of the population, because according to these data should be made reforms aimed at reducing certain diseases and improving the efficiency of health systems.

\section{Research Objectives and Hypotheses}

The present research refers to four indicators, namely births, deaths, marriages and divorces.

In this article we aim to highlight the evolution of statistical indicators on life events (birth, death, marriage, divorce) in Romania from January 2019 to May 2021, a comparative analysis of the natural movement of the population at national level and identifying the effects of the health crisis on the natural movement of the population at national level starting with March 2020 and until now. In this respect, the indicators mentioned above are defined as follows:

- The born alive is the product of the conception, from the moment of the extraction from the mother's body, who, after separation, shows signs of life (Order No 359/2012 of 25 April 2012 regarding the critteria for registration and declaration of new born);

- Death is when a persons's vital functions ceased definitively at some time after his birth;

- The diference between births and deaths in a given period represents the natural increase; 
- Marriage refers to the legally concluded union between a woman and a man, in order to start a family, resulting in rights and obligations between the two spouses (Romanian Parliament, 2011);

- We call divorce the process of dissolving a legally concluded marriage, by a final decision of the civil status officer, the court or a notary public.

The research hypotheses from which we start are:

- The number of deaths recorded by civil status services is higher in 2020 compared to previous year;

- The number of births has not been significantly influenced at national level in the last 15 months (March 2020-May 2021), compared to 2019;

- The situation of divorces registered an ascending evolution in 2020 compared to 2019;

- The number of birth has not been significantly influenced in the last months (March 2020 - May 2021), compared to 2019.

The basis for this case study is the official statistics at local and national level (National Institute of Statistics, 2021 in the period January 2019 - February 2021).

\section{Statistics at national level regarding births, death, marriages and divorces in Romania in the period January 2019 - May 2021}

We present, in the following, the natural movement of the population in Romania, i.e. the number of live births, deaths, natural increase, marriages and divorces, using monthly reports prepared in each responsible unit and cumulated data at national level.

The data in Table 1 are from each month of 2019. A first observation can be made regarding the natural increase, which remains negative throughout the year, being higher mainly in January, February, March, April and December, and the lowest being between July and October. Most marriages took place between May and October, and the number of divorces is constant, except for January, when it did not exceed 896 cases. 
The Natural Movement of The Population in The Context of the Pandemic... Irina BILOUSEAC \& Andra Ioana DURLEŞTEANU (MECHIŞ)

Table 1. Natural movement of the population in Romania in the period January-

December 2019

\begin{tabular}{|c|c|c|c|c|c|c|}
\hline \multirow{2}{*}{2019} & \multicolumn{6}{|c|}{ Natural movement of the population } \\
\cline { 2 - 7 } & $\begin{array}{c}\text { Live } \\
\text { births }\end{array}$ & Deaths & $\begin{array}{c}\text { Natural } \\
\text { increase }\end{array}$ & Marriages & Divorces & $\begin{array}{c}\text { Deceased } \\
\text { under age } \\
\text { 1 }\end{array}$ \\
\hline Jan & 16969 & 26836 & -9867 & 5270 & 896 & 104 \\
\hline Feb & 12374 & 22110 & -9736 & 5287 & 2360 & 83 \\
\hline Mar & 12559 & 22889 & -10330 & 6223 & 2766 & 104 \\
\hline Apr & 12791 & 21351 & -8560 & 5259 & 2213 & 104 \\
\hline May & 15992 & 21503 & -5511 & 12789 & 2714 & 89 \\
\hline Jun & 14506 & 19871 & -5365 & 14338 & 2431 & 105 \\
\hline Jul & 18523 & 20765 & -2242 & 16392 & 2284 & 112 \\
\hline Aug & 18408 & 19776 & -1368 & 22617 & 2770 & 107 \\
\hline Sept & 17707 & 19046 & -1339 & 15394 & 2503 & 84 \\
\hline Oct & 18230 & 21010 & -2780 & 11384 & 2477 & 97 \\
\hline Nov & 15171 & 20696 & -5525 & 6739 & 2525 & 72 \\
\hline Dec & 14959 & 24083 & -9124 & 6901 & 2355 & 94 \\
\hline
\end{tabular}

Source: National Institute of Statistics, 2020a, https://insse.ro/

In Table 2 regarding the natural movement of the population in Romania during January-December 2020, data can be observed regarding the same four indicators analyzed previously. This time the natural increase suffered a negative explosion in November and December, when the number of deaths increased significantly, and the negative natural increase doubled compared to October and tripled compared to other months, such as May, June or July. This coincides with the onset of the second wave of coronavirus infections in Romania.

Table 2. Natural movement of the population in Romania in the period January-

December 2020

\begin{tabular}{|l|c|c|c|c|c|c|}
\hline \multirow{2}{*}{2020} & \multicolumn{6}{|c|}{ Natural movement of the population } \\
\cline { 2 - 7 } & $\begin{array}{c}\text { Live } \\
\text { births }\end{array}$ & Deaths & $\begin{array}{c}\text { Natural } \\
\text { increase }\end{array}$ & Marriages & Divorces & $\begin{array}{c}\text { Deceased } \\
\text { under age } \\
\mathbf{1}\end{array}$ \\
\hline Jan & 15971 & 23352 & -7381 & 4356 & 836 & 91 \\
\hline
\end{tabular}




\begin{tabular}{|l|c|c|c|c|c|c|}
\hline Feb & 12127 & 21699 & -9572 & 5864 & 2184 & 102 \\
\hline Mar & 11857 & 22591 & -10734 & 4053 & 1889 & 83 \\
\hline Apr & 12098 & 21812 & -9714 & 1409 & 1381 & 94 \\
\hline May & 12873 & 20249 & -7376 & 2488 & 1137 & 77 \\
\hline Jun & 14786 & 21073 & -6287 & 5389 & 2355 & 83 \\
\hline Jul & 17415 & 22417 & -5002 & 11168 & 1863 & 101 \\
\hline Aug & 16804 & 23169 & -6365 & 14929 & 1953 & 88 \\
\hline Sept & 18036 & 31973 & -3937 & 12471 & 2371 & 104 \\
\hline Oct & 16546 & 27491 & -10945 & 9990 & 2545 & 107 \\
\hline Nov & 13754 & 34769 & -21015 & 4639 & 1987 & 84 \\
\hline Dec & 15857 & 36116 & -20259 & 4453 & 2245 & 85 \\
\hline
\end{tabular}

Source: National Institute of Statistics, 2020b, https://insse.ro/

As can be seen in Table 3, at the beginning of 2021 the natural increase had a positive evolution compared with the end of 2020.

Table 3. Natural movement of the population in Romania in the period January-

May 2021

\begin{tabular}{|c|c|c|c|c|c|c|}
\hline \multirow{2}{*}{2021} & \multicolumn{6}{|c|}{ Natural movement of the population } \\
\cline { 2 - 7 } & $\begin{array}{c}\text { Live } \\
\text { births }\end{array}$ & Deaths & $\begin{array}{c}\text { Natural } \\
\text { increase }\end{array}$ & Marriages & Divorces & $\begin{array}{c}\text { Deceased } \\
\text { under age 1 }\end{array}$ \\
\hline Jan & 13852 & 28390 & -14538 & 4139 & 713 & 86 \\
\hline Feb & 11816 & 23720 & -11904 & 4859 & 2214 & 83 \\
\hline Mar & 13606 & 29899 & -16293 & 5421 & 2702 & 91 \\
\hline Apr & 12664 & 29518 & -16854 & 4443 & 2421 & 82 \\
\hline May & 13524 & 24527 & -11003 & 9652 & 2176 & 60 \\
\hline
\end{tabular}

Source: National Institute of Statistics Suceava, 2021

In the above tables it can be seen that in 2020 the number of deaths increased significantly in the last three months of the year compared to the same months in 2019, and in the first two months of 2021 there is a decreasing trend in the number of deaths compared to October, November and December of 2020, their number remaining, however, higher than that recorded in the same months of the previous year (October, November, December 2019). The number of deaths increases significantly in March May 2021. 
Regarding births, there are no differences, implicitly significant increases or decreases in their number during January 2019 - December 2020. In 2021, during the months of January - May, the number of births was relatively constant, only slightly lower than from previous years. The same can be said about the number of divorces, which did not show significant upward or downward trends. But we cannot observe the same thing about the number of marriages. If in 2019, between June and September, when most marriages are celebrated, a minimum of 14,338 and a maximum of 22,617 applications were registered in a month, at national level, in 2020, in the same period, the number did not exceed 14,929, this number being reached in August. This means that the restrictions imposed by the pandemic have negatively affected certain life events, especially marriages and deaths.

\section{Conclusions}

Starting from the hypotheses of the present research, we will analyze the results obtained following the study on the natural movement of the population in Romania, implicitly the four observed indicators.

The upward trend in the number of deaths in 2020 in the context of the health crisis

Regarding the number of deaths registered at national level, it was possible to observe an upward trend of deaths registered in the civil status services compared to 2019, especially in the last three months of the year October, November and December 2020. Therefore, in Romania, in the months indicated above, 27,491, 34,769 and 36,116 deaths were registered, respectively. These months coincide with the onset of the coronavirus pandemic and the second wave of infections. Therefore, the hypothesis "The deaths registered at national level in the civil status services are higher in 2020 compared to the previous year" is confirmed.

The downward trend in the number of marriages 2020 caused by the restrictions imposed by the pandemic

The number of marriages officiated within the civil status services on the Romanian territory decreased significantly during 2020 compared to 2019. The biggest difference could be observed in May, when in 2019 12,789 
marriages were registered at national level, and in 2020 only 2,488. In MayOctober of each year, most marriages are celebrated, but in 2020, even if the number was high compared to the other months of the year, they were significantly lower than in 2019.

This significant decrease coincides with the restrictions imposed by the pandemic during that period, implicitly the state of emergency that was established.

Therefore, the hypothesis "The number of marriages decreased in 2020 compared to 2019, due to the restrictions imposed by the COVID-19 pandemic." is confirmed.

The increasing number of divorces in 2020 in the context of the pandemic

An unexpected aspect of the analysis of data on the number of divorces across the country is that their number decreased in 2020 compared to the previous year. At the national level, after the onset of the pandemic, only September, October and December registered more than 2,000 divorces, while in 2019, more than 2,000 divorce certificates were issued each month, except for January. Therefore, the hypothesis "The divorce situation registered an upward trend in 2020 compared to 2019" is refuted.

\section{Insignificant influence on the number of births in 2020 of the pandemic}

Regarding the number of live births registered at the civil status services and reported to public authorities and other institutions, following the study conducted both at national level, it was found that this indicator was not significantly influenced in 2020, but not in the first mid-2021 (January-May), with no significant differences compared to 2019. Therefore, the hypothesis "The number of births has not been significantly influenced in recent months (March 2020 - May 2021)" is confirmed.

In conclusion, since its inception in March 2020, in Romania, the coronavirus pandemic has left its mark and influenced many aspects of people's lives. Two of the mentioned indicators have been significantly influenced by the current health crisis. It's about deaths and marriages. Making a comparison between 2019 and 2020, it was found that the number of deaths increased significantly with the advent of the second wave of 
The Natural Movement of The Population in The Context of the Pandemic... Irina BILOUSEAC \& Andra Ioana DURLEŞTEANU (MECHIŞ)

infections. As for the other two indicators, namely, the number of live births and the number of divorces registered with the state services, the data available so far have not shown a significant influence of the pandemic on them.

\section{References}

Ministry of Health. (2012). Ordinul nr 359 din 2012 privind criteriile de inregistrare si declarare a nou-nascutului [Order No 359/2012 of 25 April 2012 regarding the critteria for registration and declaration of new born], Monitorul Oficial, partea I, 237, 9 aprilie 2012 [Official Gazette of Romania, Part I, no. 237 of April 9, 2012]. http://legislatie.just.ro/Public/DetaliiDocument/136983

National Institute of Statistics (2020a). Mişcarea naturală a populației [Natural movement of the population in Romania] [Press release]. Institutul National de Statistică, No. 32 / 10 februarie 2020 [National Institute of Statistics, No. 32 / february 10, 2020]. https://insse.ro/cms/ro/tags/comunicatmiscarea-naturala-populatiei

National Institute of Statistics Suceava (2021). Monthly Statistical Bulletin, May 2021, Suceava. Direcția Județeană de Statistică Suceava[Suceava County Directorate of Statistics] https://suceava.insse.ro/produse-siservicii/publicatii-statistice/

National Institute of Statistics. (2020b). Mişcarea naturală a populației [Natural movement of the population in Romania] [Press release]. Institutul National de Statistică, 70/16 martie august 2020 [National Institute of Statistics, No. 70 / march August 16, 2020]. https://insse.ro/cms/ro/tags/comunicatmiscarea-naturala-populatiei

National Institute of Statistics. (2021). Mişcarea naturală a populației [Natural movement of the population in Romania] [Press release]. Institutul National de Statistică, 287 /10 Noiembrie 2021 [National Institute of Statistics, No. 278 / November 10, 2021]. https://insse.ro/cms/ro/tags/comunicatmiscarea-naturala-populatiei

Romanian Parliament. (2011). Codul civil [Civil Code], Monitorul Oficial al României, Partea I, 409, 10 iunie 2011 [Official Gazette of Romania, Part I, no. 409 of June 10, 2011], https://legislatie.just.ro/Public/DetaliiDocumentAfis/129592 